\title{
Tidsskriftet på engelsk
}

I mars 2007 ble Tidsskriftets første engelske oversettelse av en originalartikkel publisert (1). Artikkelen var først utgitt på vanlig måte i Tidsskriftet nr. 1/2007 (2). Den ble så oversatt og publisert sammen med den norskspråklige i Tidsskriftets nettutgave. Til å begynne med var dette et prøveprosjekt som bare gjaldt originalartikler, men fra 2008 ble tilbudet utvidet til å omfatte alle artikler med engelsk sammendrag (3). I løpet av to år er nærmere 30 artikler blitt oversatt (4). Hensikten var og er å gjøre artikler i Tidsskriftet lettere tilgjengelig for utenlandske lesere. Dette er ikke et skritt på veien til å gjøre Tidsskriftet til en engelskspråklig publikasjon.

Å publisere betyr å offentliggjøre. Tidsskriftets målgruppe var opprinnelig norske leger - eller mer presist medlemmer i Legeforeningen. Slik er det fortsatt, men i løpet av de siste årene er leserkretsen blitt utvidet Fra år 2000 har Tidsskriftet vært åpent tilgjengelig i fulltekst på Internett for alle. Vi vet at mange av brukerne av nettversjonen er ikke-leger og at de kommer fra mange land - ikke minst har utenlandsstudentene benyttet seg av tilbudet. Nye lesere krever annen form for tilrettelegging av artiklene - både pedagogisk og språklig. Det er en utfordring vi med glede tar. Poenget med å publisere gode artikler er jo nettopp å nå frem til flest mulig.

Det er ikke noe nytt at man har ønsket å gjøre artiklene kjent for et større publikum. Tidsskriftet begynte allerede i 1945 med engelsk sammendrag til de vitenskapelige artiklene (5). Fra 2003 har disse vært publisert kun på Internett - i Tidsskriftets nettutgave og i elektroniske databaser som bl.a. PubMed.

Å finne frem i den medisinske informasjonsjungelen er både lettere og vanskeligere enn det var før. Et av de viktigste hjelpemidlene er nettopp elektroniske databaser på Internett. Den fremste bibliografiske databasen innen biomedisin er PubMed, som produseres av National Library of Medicine i USA og omfatter artikler fra mer enn 5000 tidsskrifter (6). Siden vi nå publiserer engelske fulltekstversjoner av artikler, er det viktig at disse artiklene blir søkbare og tilgjengelige i de elektroniske databasene. Artikler fra Tidsskriftet merkes i PubMed med «Article in Norwegian». Det gjelder selv om de senere også foreligger i engelsk versjon. Det er uheldig, fordi brukere av PubMed da ikke vil få vite om den engelskspråklige versjonen. Vi hadde håpet å løse dette ved å få PubMed til å legge til denne informasjonen i etterkant, men det lar seg ikke gjøre. I januar 2009 var deler av redaksjonen på studietur til National Library of Medicine i Bethesda, Maryland - verdens største medisinske bibliotek. Et av formålene med turen var å finne en løsning på dette problemet. Det ser ut til å bli at vi publiserer den engelske og den norske versjonen av artikkelen samtidig. Da vil de bli merket: «Article in Norwegian, English». Dette gjøres allerede for tospråklige tidsskrifter, som f.eks. Weekly Epidemiological Record (7). Denne ordningen gjør publiseringsprosessen noe mer tidkrevende det vil ta lengre tid fra et manus er godkjent for publisering til det er utgitt på de to språkene.

En engelskspråklig versjon av artiklene er aktuelt for ulike grupper. Flere stipendiater har henvendt seg til redaksjonen med ønsket om å publisere en av artiklene i avhandlingen i Tidsskriftet. Ettersom bedømmelseskomiteene ofte består av minst ett engelskspråklig medlem, må artikkelen også finnes på engelsk. Også artikler om norsk helsetjeneste og kliniske oppfølgingsstudier i Norge kan være aktuelle. Dette stoffet har selvsagt størst innenlands betydning, og internasjonale tidsskrifter er ofte mindre interessert i å publisere disse artiklene. Men innholdsmessig kan de være interessante for klinikere og helsetjenesteforskere $\mathrm{i}$ andre land som arbeider med å forbedre sitt eget lands helsevesen.

Er oversettelse av norske artikler et skritt på veien til å gjøre Tidsskriftet til en engelskspråklig publikasjon? Nei. I Tidsskriftet har vi $i$ alle år arbeidet aktivt for å fremme et godt norsk medisinsk fagspråk. Det ønsker vi å fortsette med. Det er en rekke grunner til det, ikke minst behovet for å kunne snakke med pasientene våre - på norsk. Skal man nå norske lesere - både pasienter og leger - gjør man det fortsatt enklest og sikrest ved å skrive norsk (8).

Hvor stor del av Tidsskriftets innhold som også skal publiseres på engelsk, kan diskuteres. Kan f.eks. lederartikler og kommentarer som ikke har hatt engelsk sammendrag til nå - være aktuelle, interessante og viktige for en større leserkrets?

Det er også noen praktiske problemer som må løses. En god oversettelse er ressurskrevende og forutsetter både språklig og faglig kompetanse. Hittil er artiklene blitt oversatt fra norsk til engelsk av en oversetter - og deretter kvalitetssikret av forfattere og medisinske redaktører i Tidsskriftet. Dette vil fortsatt være en mulighet. Men mange av forfatterne behersker den engelsk fagterminologien godt. På det årlige møtet for Tidsskriftets faglige medarbeidere i mars 2009 ble det foreslått at forfatterne kunne gjøre den første oversettelsen selv og Tidsskriftet besørge språkvasken. Det er et godt forslag som vi vil prøve ut.

Tilbudet om oversettelse av artikler i Tidsskriftet til engelsk har eksistert i over to år. Vi går nå et par skritt videre. Forfatterne får anledning til å oversette selv, den engelske og den norske versjonen av artikkelen publiseres samtidig og blir indeksert med begge språk i databasene.

\section{Erlend Hem}

medisinsk redaktør

\section{Charlotte Haug}

redaktør

\section{Litteratur}

1. Halvorsen I, Meland E, Bærheim A. Use of emergency services before and after implementation of the Regular General Practitioner Scheme www.tidsskriftet. no/index.php?seks_id_eng=8642\&seks_id=1472139 (28.5.2009).

2. Halvorsen I, Meland E, Bærheim A. Bruk av legevakt før og etter fastlegeordningen. Tidsskr Nor Lægeforen 2007; 127: 15-7.

3. Tidsskrift for Den norske legeforening. Artikler på engelsk. www.tidsskriftet.no/ ?nota_id=1065 (28.5.2009).

4. Tidsskrift for Den norske legeforening. The Journal of the Norwegian Medical Association. www.tidsskriftet.no/index.php?nota_id=7 (28.5.2009).

5. Ødegaard R. Språket i Tidsskriftet. Tidsskr Nor Lægeforen 2006; 126: 71

6. The National Library of Medicine. Fact sheet. www.nlm.nih.gov/pubs/factsheets/ $\mathrm{nlm} . \mathrm{html}(28.5 .2009)$

7. Swine influenza: frequently asked questions. Wkly Epidemiol Rec 2009; 84 : 149-51. www.ncbi.nlm.nih.gov/pubmed/19408352 (2.6.2009).

8. Gulbrandsen P. Schroeder TV, Milerad J et al. Skjerm eller papir, morsmål eller engelsk - hva er best? Tidsskr Nor Lægeforen 2002; 122: 1646-8. 